\title{
Noble Robbers, Avengers and Entrepreneurs: Eric Hobsbawm and Banditry in the Middle East and North Africa
}

Banditry, on land and sea, and allied trades such as smuggling, have been widespread and endemic across the Middle East and North Africa. That this is so is attested to by a variety of sources, some hostile and emanating from elite origins, state archives, court records, chronicles, accounts of European travellers, and some more sympathetic, popular song, poetry and folklore. Yet the Middle Eastern experience of banditry has thus far failed to receive sustained academic attention and the figure of the bandit has found fuller representation in literature, most notably in the novels of the Turkish author Yashar Kemal. ${ }^{1}$ In particular, the debates stimulated by Eric Hobsbawm's thesis of social banditry has elicited only a few responses from scholars of the Middle East and North Africa, and those largely negative, failing to spark the kind of comparative and theoretical interest that has proved so productive for Latin America, China and southern Europe. ${ }^{2}$

The publication of Eric Hobsbawm’s ‘Bandits’ in 1969 was a foundational event. ${ }^{3}$ Although criticized as methodologically unsound, theoretically flawed, empirically limited and latterly, after its influence had spread among scholars working on the non-European world, as Eurocentric, the book itself and its central notion of social banditry are still, several decades after its first appearance, compulsory referential starting points for any discussion of banditry, of pre-modern rural crime, indeed for the social history of crime in general. Even though the search for the social bandit often failed, the quest itself has offered productive ways of thinking about contested definitions of crime, the nature and scope of peasant resistance and the subaltern psychological world.

Hobsbawm's location of social banditry within a world of peasant resistance was originally part of a wider intellectual endeavour aimed at redefining the phenomenon of crime, the criminal no longer simply a pathological individual but criminal action a rational activity. ${ }^{4} \mathrm{~A}$ further step was taken as crime came to be seen as, under certain conditions, a form of subaltern resistance, conscious or unconscious, and an embryonic form of social protest. Especially in the context of the arrival of modernity, exemplified by eighteenth century England and entailing the disintegration of pre-capitalist social and economic structures and the ruthless consolidation of new "modern" relationships enforced by harsh and novel legal, judicial and penal systems, lawbreakers and outlaws of every kind, food rioters, smugglers and poachers, along with bandits and pirates, were rehabilitated, emerging as crypto- or proto- rebels.

Hobsbawm's thesis of social banditry was a contribution to this wider historical revisionism. For Hobsbawm, this specific form of rural crime functioned as a manifestation of peasant protest, the designation of social bandit applying to peasant outlaws whom the authorities regarded as criminals, but who remained within their own peasant communities, and were 'considered by their people as heroes, as champions, avengers, fighters for justice, perhaps even leaders of liberation, and in any case as men to be admired, helped and supported'. ${ }^{5} \mathrm{He}$ insisted on the essential connection between the peasantry and social banditry, rejected modern forms of urban terrorism or gang activity as banditry, and clearly distinguished social banditry from both the professional underworld of common robbers and communities, such as beduin, for whom raiding was a normal economic activity. As well as the noble robber, Hobsbawm identified the avenger, who shared many of the characteristics of the noble robber, and was also a symptom of peasant discontent, but for whom to be 'terrifying and 
pitiless' was at least an important as being a friend of the poor. ${ }^{6}$ A third type, the haiduk, largely a Balkan phenomenon, was rather more particular. In addition to living by robbery, the haiduk was also and equally a patriot, even a nationalist, and a fighter against foreign (usually Ottoman) oppression.

It should be noted, firstly, that Hobsbawm's social bandit was a rather conservative figure, his actions a form of protest against intolerable conditions, lacking any vision of social transformation and often aiming at a return to an idealized past. Only rarely, and under strictly circumscribed historical conditions, could such social bandits summon the potential to transcend the parochial limitations of peasant ideology and politics and assume a revolutionary role. Secondly, Hobsbawm, his conceptualization rather more subtle than his critics allowed, suggested social banditry only as one variant of banditry, and did not claim that all bandits or bandits in general fell into this category, this vulgarization of his original thesis later becoming rather widespread among his critics. ${ }^{7}$ He particularly distinguished the social bandit from two quite separate categories of rural brigands, simple robbers or rural desperadoes, and bandit gentry or robber barons, warlords in contemporary Middle Eastern parlance.

Two lines of objection to the Hobsbawmian social bandit appeared immediately. The first and perhaps most obvious was his romanticization of the phenomenon, based on an uncritical use of the literature and legend of banditry. As he himself later conceded, very little about the historical reality of social banditry, let alone the careers of specific individual bandits, might actually be inferred from the songs sung and the stories. ${ }^{8}$ The second objection was to his equally uncritical acceptance of Balkan nationalist historiography for his construction of the haiduk. ${ }^{9}$ The first charge against Hobsbawm was originally elaborated in an extremely influential article by Anton Blok. ${ }^{10}$ Basing his critique on his research into the Sicilian mafia, Blok argued that any analysis of banditry must look at the actual behaviour and actions of bandits, not on their popular perception. Blok insisted that far from representing the grievances and incipient defiance of their own peasant communities, bandits rather developed connections to local elites, landlords and others, to whom they looked for political protection and for whom they actually acted as enforcers against the peasants, citing as evidence the Sicilian Giuliano Salvatore's attacks on communists and trade unionists just after the second world war, and his contemporary, Luciano Leggio's reign of terror against peasants mobilizing to demand agrarian reform. ${ }^{11}$ In addition, banditry offered the bandit social mobility and an escape from peasant life and, by siphoning off young unmarried men, the most combative elements of village society, removed potential footsoldiers of revolt. Far from challenging local power structures, Blok concluded that banditry contributed both materially and ideologically to weakening the capacities of peasants to resist.

The polarities offered by Hobsbawm and Blok were taken up and explored by scholars working within and across a range of disciplines and geographical regions to produce an increasingly sophisticated body of work on bandits and banditry. The taxonomic approach, sometimes reduced to the simple question of whether the social bandit existed or not, was soon superseded by inquiries into methodology and meaning. The distinction between bandit reality and bandit mythology quickly came to be generally acknowledged, including by Hobsbawm himself. It was not conceded, however, that this meant that the social bandit could be dismissed as a mere figment of the imagination. The almost universal existence of Robin Hood legends across the world suggested, on the contrary, their profound historical, political and social significance. ${ }^{12}$ As a consequence, both sympathizers of the social bandit thesis and those sceptical of the thesis, and occasionally also of the politics behind it, began 
to take a closer and more contextualized look at the folklore itself, interrogating the production, transmission, transmutation, and, perhaps most importantly, reception, of stories of bandit heroics. A number of case studies painstakingly deconstructed bandit legends, tracing their manipulation within the strategic discourses of power-seeking elites, particularly an urban nationalist intelligentsia. Perhaps the most comprehensive such deconstruction was that of Balkan nationalism's romanticization of the bandit klephts and haiduks. Although preying ruthlessly on the peasantry and motivated largely if not exclusively by the prospect of booty, klephts and haiduks became the embodiment of anti-Ottoman freedom-fighting in Balkan nationalist historiographies, myths about brigand heroes manipulated by postindependence ruling classes. ${ }^{13}$ Again, the Lithuanian popular cultural icon, Tadas Blinda, 'a leveller of the world', who was reputed to take from the rich and give to the poor, seems to have been in fact a horse-thief lynched by an angry mob who was transformed into a noble bandit by urban intellectuals first in the service of Lithuanian nationalism and later, in the Soviet period, as a progenitor of peasant class struggle. ${ }^{14}$ Nonetheless such demolitions still failed to account for the origins of the myths in folk culture and their enthusiastic embrace by all manner of subalterns. The dynamics of myth-creation remain complex. Where and how the myth originates is as important, though harder to trace, as the way in which it is subsequently shaped. Popular responses to literary reworking of oral or folk history have, in their turn, their own impact on future cultural representation. The bandit himself may even strive to conform to the script. Far from reducible to a unilinear process whereby harsh peasant reality is appropriated and glamourized by a remote literati, subalterns as well as elites each make their own contributions to the profoundly contested meaning of bandit legends. ${ }^{15}$

Hobsbawm's own interest in banditry had originated in an interest in peasant discontent and resistance. The centrality of a focus on the meaning of banditry in peasant consciousness and the place of crime in class conflict was famously reasserted by Ranajit Guha in his study of colonial India published thirty years after Hobsbawm's book. Guha pointed out, firstly, that the peasant was typically prepared to tolerate, and 'often positively approve of a wide variety of crimes induced by poverty'. ${ }^{16}$ Secondly, actual peasant revolt was preceded by a 'wave of "preliminary outrages", an increase in rural criminal activity which a often a feature of during periods of immiseration and which signalled a lowering of the peasant's tolerance of his conditions of existence. ${ }^{17}$ Thirdly, such rural crime, including banditry, possessed an inversive function, symbolically or explicitly challenging social hierarchies and codes of deference, introducing a blurring within which peasants were increasingly enabled to invest rural lawbreaking and violence with new meanings, such code switching facilitated by the fact that the peasants' attitude towards activities labelled as crime in any case differed greatly from that of their class antagonists. ${ }^{18}$

Guha's direction of attention towards the necessity of interpreting sources differently in order to gain access to the consciousness of both peasant and bandit was made within the context of wider methodological debates. ${ }^{19}$ Although Hobsbawm himself acknowledged the difficulties raised by his reliance on folklore and literature, his supporters countered that sceptics of the social bandit themselves often neglected to interrogate their own reliance on written texts emanating from elite sources, especially police and judicial records. Such sources, in addition to reflecting a tendency to conflate all types of rural lawbreaking into a single undifferentiated criminal category, were in particular hardly likely to reflect any popular perceptions or bandit self-images of legitimate resistance. Whereas state archives might be useful for chronologies of action, they say little, might even be profoundly misleading, about meaning. A single action, or category of activity, might appear to the authorities and 
therefore in the archives under the catchall rubric of banditry, but might have been interpreted by the achivally silent lower echelons of rural society as invested with defiance, resistance or protest. Much work on banditry in the Middle East has indeed displayed a sometimes unconscious privileging of the written text, an assumption that elite-generated archival sources are relatively free of the subjectivity and bias which allegedly mars orally transmitted material. This approach has been particularly problematic where the events addressed are within living memory and popular voices thus easily accessible.

Another and quite novel line of criticism emerged when feminist scholarship began to try to gender Bandit studies. This endeavour did not only involve the search for female bandits but examined such issues as the division of labour within peasant societies which might facilitate bandit activity, the role of extended households and domestic organization. ${ }^{20}$ Gender studies particularly asked whether the continuing interest in banditry concealed a romantic view of male violence. ${ }^{21}$ Certainly for southern Europe and the Middle East and North Africa, deeply embedded cultural codes of honour and shame and notions of masculinity have been identified as important tropes in shaping popular sympathies for a range of picaresque figures on the margins of, or even outside, social and legal boundaries.

To what extent, then, does the recent work done in the wider field of Bandit studies help to elucidate the experience of the Middle East and North Africa? Firstly, how can we explain the absence of the Middle East and North Africa from the historical controversies described above? Why has there been such a lack of interest in banditry when the phenomenon itself, and rural crime in general, was so widespread? Why are so few individual bandits celebrated or reviled? Why is there no Middle Eastern or North African counterpart to the Mexicans Zapata or Pancho Villa, the Brazilian Lampiao, the Australian Ned Kelly, the Sicilian Salvatore Guiliano, or the Chinese Bai Lang, let alone to the female Indian 'bandit queen', Phoolan Devi. ${ }^{22}$ What do we mean by banditry in the Middle Eastern context, who became a bandit, why and in what circumstances, what did bandits do and how was this perceived by elites and subalterns, what were the connections between bandits and peasants and between bandits and the worlds of power and, perhaps most importantly, who has written about bandits and what sources have they used?

Hobsbawm's elaboration of the concept of social banditry as a form of peasant protest was largely based on his analysis of European history. His central concept, however, proved particularly tempting to scholars working on the non-European world where both numerically preponderant peasant populations, and banditry itself, either still existed or were a very recent memory. This was particularly the case for parts of the world which had still living traditions of peasant populism, especially Latin America, or where peasants, and their fringe of bandits, had been allocated a politically salient historical role and their activities incorporated into a hegemonic discourse, most notably China. ${ }^{23}$ Unfortunately, neither of these conditions held true for the Middle East and North Africa. Although in every country of the region the vast majority of the population was, until very recently, rural, national historiographies have been dominated by the politics of urban elites. In contrast to nationalisms elsewhere, Middle Eastern varieties have in general not valued the peasantry as the living reservoir of an authentic "national" culture but have rather tended to exclude the rural areas and those who inhabited them from both actual political action and from the imagined historical community.

One reason for the lack of interest in banditry in the Middle East and North Africa and scepticism of social banditry in particular may, therefore, be found in the fact that, in general, bandits have not been incorporated as heroic figures into nationalist historiographies or state- 
building ideologies. The major exception is the Balkans under Ottoman rule, where a specific construction of banditry, Hobsbawm's klephts and haiduks, became central to an elite liberation discourse, and where, accordingly scholarship followed. In relation to the central lands of the Middle East and North Africa, however, banditry has been allocated rather the contrary role. Here state-building was often authoritarian and undertaken at the initiative of entrenched rulers and elites. With certain partial exceptions, for example colonial North Africa and mandatory Palestine, there was no place here for the revolutionary haiduk, let alone a Zapata. Across the Middle East, an anti-bandit discourse was appealing to indigenous elites and to colonial and imperial authorities alike, elite oppositional movements also sharing this perspective. Even the radical posy-1967 Palestinian nationalist movement found peasant approbation of certain well-defined types of banditry somewhat embarrassing as a manifestation of backwardness. ${ }^{24}$

Nonetheless, a small number of scholarly engagements with the phenomenon of banditry in the Middle East have emerged. Three of the most significant are those of Nathan Brown on late nineteenth century Egypt, of Karen Barkey on the seventeenth century Ottoman empire, and of Andrew Gould on nineteenth century Anatolia. Yet all three reject the notion of social banditry and find the significance of banditry in its connection to the worlds of power, and more specifically to its role in state-building. ${ }^{25}$ For both Brown and Barkey, for example, bandits were an unmitigated curse and a tool of oppression, perpetrators of violence against and exploitation of a helpless peasantry and in league with local power-holders of every kind. Brown goes even further than Anton Blok, stressing the complete self-interest of bandits, no more tied to the interests of notables than representing those of peasants. ${ }^{26}$

Brown's main interest is in the utilization of an anti-banditry discourse in the pursuit of an elite nationalist state-building project. In late nineteenth century Egypt, the khedivial government, struggling to survive, based its resistance to the encroachment of British imperial power and its claims to legitimacy on its ability to maintain security in the countryside. ${ }^{27}$ Indeed the Egyptian elite shared its fear of rural native defiance with Britain and was at least as concerned as the British about its own physical safety and the security of its property. Here, unlike the Balkans, no nationalist leadership unleashed the power of bandits across the vast rural hinterland in a challenge to foreign authority, nor did a nationalist intelligentsia celebrate the valour and deeds of brigand heroes. On the contrary, Brown shows how, in the 1880s, immediately after the British occupation, the khedivial authorities discovered, or perhaps invented, an unprecedented crisis of violent rural crime, deploying this imagined crisis for two purposes: to enhance their claims to sovereignty vis a vis the British, and to strengthen their control over their own peasantry, using the banditry "crisis" as a justification for an ambitious state-building agenda, constructing new and strengthening existing disciplinary institutions, including a centralized police force, prisons and courts and national legal codes. The newly-established and draconian Brigandage Commissions failed and were abolished in 1889. But the British occupying authorities then appropriated the ideological weapon forged by the khedivial government and turned it against its creators, using the continuing rural insecurity to justify their own increasing presence within the Egyptian administration. Yet the discourse of order remained as central to the British as it had been to the Egyptian authorities, and the bandit continued as the symbolic representative of chaos and violence, a threat to life and property of Egyptians and British alike.

For Barkey, closely following Blok, bandits were certainly a feature of the drastic material deterioration in the Ottoman empire typical of the global crisis of the seventeenth century, but 
their significance lay in their ambitions vis a vis the patrimonial Ottoman state, not in representing a rebellious peasantry. ${ }^{28}$ Their proliferation was a direct consequence of Ottoman state-building, as they were recruited into new regular armies, trained in the use of weapons, but then casually demobilized. Cast adrift, they became mercenaries, either joining the retinues of local warlords or notables, or turned themselves into bandit gangs, becoming instruments of repression in the hands of landlords, officials, or warlord-rebels. The Ottoman government responded with a policy of bargaining and incorporation. Where possible, bandit gangs which became too menacing were suppressed by force. More frequently they were simply absorbed, their leaders offered state appointments, successful elite incorporation indeed, according to Barkey, the main objective of bandit activity. ${ }^{29}$

Certainly, as Brown and Barkey argue, banditry across the Middle East and North Africa, as elsewhere, was often not exclusively a subaltern activity. Bandits often possessed, as Blok noted in relation to Sicily, a symbiotic relationship with such rudimentary forces of law and authority as existed on the local level, collusion sometimes open, sometimes covert, bandits acquiring protection in return for a share of the loot. For the Middle East and North Africa, this was especially the case where tribal ties of kinship, real or fictive, linked bandits directly to local landowners or state officials. Banditry might even constitute a route of upward social mobility. Bandit figures often intruded into the politics of pre-Modern Middle Eastern and North African states, thereby forcing themselves into the archives, but they resembled Hobsbawm's robber barons, not his social bandit. The offer of elite incorporation in return for submission was a central strategy of states for dealing with all troublesome or rebellious elements which were too powerful to suppress and bandit leaders and local warlords often graduated into legitimate and high-ranking official positions. Their performance of power notwithstanding, pre-modern Middle Eastern and North African governments and their armies were in reality small and weak, lacking the material means to enforce their will across large territories, and political survival depended on an ability to manipulate and accommodate a variety of interests with only the occasional application of exemplary force. Examples abound of negotiation with, and incorporation and utilization of, bandits and all manner of rural adventurers. ${ }^{30}$ A classic case of the bandit-turned-governor is that of Sharif Mawlay Ahmad al-Raysuni in nineteenth century Morocco. ${ }^{31}$ Beginning as a cattle rustler and gun-runner, al-Raysuni progressed to kidnapping and ransoming Europeans, a particularly lucrative business, establishing himself as local strongman and warlord in northwestern Morocco. He eventually obtained from the sultan of Morocco the governorship of the coastal town of Asila, from which position he went on to establish good relations with the emerging Spanish protectorate.

A case of a "bandit elite," rather than an opportunist individual, is that of the derebeys, local tribal rulers of Cilicia, in southeastern Anatolia. ${ }^{32}$ The derebeys were among the last local rulers to resist the centralizing expansion of the nineteenth century Ottoman state, surviving until the 1860s. They were notorious in Istanbul for their brigandage and a derebey was conventionally described in Ottoman documents as shaki, outlaw or brigand or possibly rebel. Their speciality consisted of presiding over gangs drawn from the local population, who held up caravans in mountain passes and raided villages on the surrounding plain, the derebeys becoming effectively "lords of the bandits". ${ }^{33}$ The Ottoman government, wishing to bring the region under its direct control but lacking the resources, and perhaps the inclination, to confront the derebeys militarily, instead approached them as a ruling elite in their own right and offered them high positions and generous salaries in return for submission. The derebeys, sharing the culture and politics of patrimonialism and, perhaps reading the writing on the wall, acceded, leaving their tribespeople to cope alone with the collapse of their economy and 
forced settlement in the plain below their mountain home. Patrimonial strategies were reserved exclusively for local elites, including bandit leaders.

Hobsbawm conceded the prevalence of such connections, between bandits and the worlds of power, but his social banditry was a quite different phenomenon, and interesting insofar as it functioned, under certain circumstances, as an articulation of peasant discontent. Barkey's rejection of the social bandit was, on the contrary, crucially embedded in a denial of the very existence of strategies of rebellion among Ottoman peasants. In her view, the failure to rebel was certainly not the result of a lack of material distress, Ottoman peasants experiencing many of the hardships which produced rural revolts across Europe during the seventeenth century. It was rather the result of the existence of preferable alternatives to the risky strategy of open defiance, Ottoman peasants, apparently lacking the profound attachment to the land typical of peasant consciousness, preferring to leave the land rather than to fight for it, straightforward criminal banditry itself becoming a favoured survival strategy of vagrant expeasants in headlong flight from their villages. ${ }^{34}$

A broader general scepticism regarding peasant rebellion may thus constitute a further reason for the general unpopularity of social banditry in studies of the Middle East. ${ }^{35}$ Much of the recent research into banditry in other areas of the world has been prompted by a more general interest in peasant resistance. As far as the Middle East and North Africa is concerned, the rise of Peasant studies as a discrete field of research in the 1970s found comparatively little response. Since the region appeared to lack the large-scale risings characteristic of countries such as China, or the politically significant peasant movements of Latin America, historians of the Middle East and North Africa tended to dismiss the countryside as uninteresting and the consciousness and agency of its inhabitants has been little investigated. If historians of the region have often been content to share Marx's characterization of peasants as so many potatoes in sacks, their view of nomads/beduin, often prime candidates for bandit gangs, has sometimes been actively hostile. Following the mediaeval scholar Ibn Khaldun, scholarship has tended to depict tribal nomads as mere instruments of their khans, any resistance from them merely a symptom of an eternal conflict between tribal chaos (the desert) and stateimposed order (the sown). ${ }^{36}$

Brown's dismissal of the social bandit in Egypt, and Barkey's in the Ottoman empire, are based largely on close reading of official documents located in state archives. That a different methodology might produce different results can clearly be seen in Barkey who, when she turns to popular traditions, becomes more sympathetic to the possible existence of social banditry. State and elite-generated sources on rural dissent, indeed on crime in general, are replete with perennial problems of interpretation: generic labelling, the subsuming of widely differing types of rural violence under the heading of crime, the use of words with the connotation of banditry/brigandage as part of a search for legitimacy. The late nineteenth century Egyptian banditry commissions, for example, lumped all rural violence together into a single undifferentiated category, the work of "miscreants" (ashqiya'). ${ }^{37}$ Barkey's use of the term banditry applies to an even more diffuse phenomenon, the so-called Celali rebels of the seventeenth century Ottoman empire. The Ottoman government referred to all its armed opponents in the countryside, whether rebel bands numbering thousands or small groups of robbers, as Celalis, using this designation to delegitimize any and all rural unrest by identifying it with the traumatic rebellion of Sheyh Celal at the beginning of the sixteenth century. ${ }^{38}$ In any case, for states such as the Ottoman empire, banditry and robbery were indeed both a form of rebellion against its authority and the sources often deployed a 
colourful vocabulary of undifferentiated abuse, individual words containing the meaning of both brigand and rebel. ${ }^{39}$

The meta-language of official sources has therefore made it difficult to disentangle the different activities of different kinds of groups. Given the strong ideological imperatives embedded in the archival material it is extremely unlikely that bandit activity, or indeed any kind of rural violence, would appear in anything other than an extremely negative light. Egyptian and Ottoman archives are, naturally enough, replete with vivid accounts of the brutality of bandits and the suffering of the poor at their hands, including petitions and appeals to courts for justice by peasants themselves. Yet none of this evidence is unmediated, the petitions of illiterate villagers and supposedly verbatim statements by bandits surviving in court records having passed equally through the filter of scribal pens. ${ }^{40}$

Although most bandit activity in the Middle East and North Africa, as Hobsbawm pointed out regarding Europe, was simple robbery and extortion targeting the accessible and defenceless poor, yet the generic labelling for ideological purposes typical of official records renders invisible different and more complex stories. Perhaps the most famous appellation of the term banditry to an authentic case of peasant resistance is the British labelling of the 1936 revolt in mandatory Palestine. British officials and press reports routinely branded the rebel peasant fighters as outlaws, bandits, gangsters and highwaymen, as a ploy to discredit the uprising's nationalist aims, a linguistic practice continued by Israeli academia. ${ }^{41}$ Another much earlier but similar contest over naming may be found in the case of the activities of postReconquista exiles (manfiyyun) in Andalusia. These Muslims and Moriscos, described as bandits in Spanish sources, have, on the contrary, been reclaimed by North African scholars as the last remnants of Moorish resistance to the Reconquista. ${ }^{42}$

The possibilities suggested by the deconstruction of contests over labelling and meaning are well illustrated in a study of colonial Algeria. ${ }^{43}$ Here we find the invention, by French settlers, of the 'myth of Algerian banditry', a myth which was then utilized to delegitimize both Algerian claims to the land and indigenous resistance to dispossession. ${ }^{44}$ This case provides a classic illustration of the social and political consequences of the revolutionary impact of capitalism on a pre-industrial economy. Across a forrested region near the city of Annaba (Bône) in northeastern Algeria, the local population maintained a precarious ecological equilibrium through a practice known as kcar, the controlled burning of the forest to obtain pastures and farmland. The arrival of increasing numbers of French colons after the conquest of Algeria in 1830 inaugurated first a struggle over concepts of land ownership and use leading to dispossession, then the criminalization of the customary practice of $k c a r$, and finally the labelling of kcar as banditry and a symbol of political and especially religious resistance. The Algerians, although they conceded formal ownership of the forest to the Ottoman landlords, believed that they too, as those who worked it, possessed rights over it. In particular, they considered the areas they cleared through their own labour as their own property, an inheritance for their children. The French colonial authorities, on the other hand, disregarded the customary claims of the Algerians and embarked on a policy of the conversion of all of the forest into pure private property and its expropriation and concession to French businessmen for commercial exploitation, specifically the production of cork. ${ }^{45}$ The Algerians' use of the forest was accordingly increasingly restricted, upon pain of punishment by large fines and collective responsibility. The Algerians responded using a variety of tactics, evading the forest guards, presenting petitions to the colonial authorities and, occasionally, deliberately burning the forest down. ${ }^{46}$ The practice of kcar had always contained the possibility that fires might accidentally get out of control. The French, 
however, could or would not distinguish accident from arson. They increasingly identified all kcar fires as arson and tried to ban the practice altogether, which for the Algerians represented a lethal assault on their way of life. The French were committed to the destruction of the indigenous political economy, and could neither recognize the legitimacy of, nor tolerate, resistance. Their solution to their dilemma, by which they made their own situation comprehensible, was to turn the Algerian resisters into bandits practising arson. ${ }^{47}$

Yet elite discourses were always capable on considerable plasticity. The case of Egypt demonstrates how the significance of activities which were, in times of political stability and elite consensus, mundanely relegated to the purely criminal might be transformed into resistance by the wider political context. The late nineteenth century Brigandage Commissions had defined all rural violence as crime. In 1919, however, similar actions by peasants, the killing of village elders, attacks on police, theft of moveable property, food, cattle, sheep and fodder, especially that which had been hoarded by the wealthy during the war, were briefly reinterpreted as manifestations of a peasant revolt, part of a national struggle, indeed a revolution, directed against the British Protectorate and in favour of independence and led by the middle class liberal nationalists of the Wafd party. ${ }^{48}$

Prevailing ideologies of modernism continued in the twentieth century Middle East to confine the bandit to the pathological margins of society, while the label was applied indiscriminately to a vast range of rural opposition. From the 1920s onwards, the new Turkish republic combined all manifestations of rural armed rural dissent, whether Kurdish nationalist, religious, peasant or robber, into a single category of bandit, this category then defined as a threat to the state and crushed. Mustafa Kemal's contemporary, Reza Shah of Iran, similarly deployed the discourse of the 'man of order' to establish the new state's physical control throughout the countryside, over rural criminals of all sorts, bandits, highway robbers and nomadic raiders, but also, and as part of the same process and often using the same justificatory vocabulary, over tribal khans and semi-autonomous local rulers and their agricultural-pastoralist populations. ${ }^{49}$ For the nationalist elite of Pahlavi Iran, the suppression of banditry was a central trope in the wider transformation of troublesome pastoral nomads into settled productive farmers. Reza Shah's son, Muhammad Reza Shah, continued the project. Although tribal power had been decisively crushed, partly by military force but mainly by socio-economic transformation, a phenomenon defined as banditry reappeared. Just as in the Turkey of the 1960s and 70s, the nomenclature of banditry was applied to Kurdish opposition in the rural areas, so in Iran, the designation bandit was applied to guerrilla movements who launched armed actions in the 1970s against the shah's regime.

The practice of nomad raiding, endemic across the pre-modern Middle East and North Africa, has also magnified uncertainties about the activities and identities of bandits. Hobsbawm himself specifically excluded communities for whom raiding was part of the normal way of life, such as nomads/beduin, from consideration as social bandits. But were such raiders, at least in their own eyes, even bandits? The literature has, in general, adopted the perspective of those who were the targets of such raiding. Yet what may be deduced regarding the perspectives of the raiders themselves? Across the Middle East, tribal nomads adopted, for example, the roles of paid protectors of caravans that carried people and goods along trade and pilgrim routes. This system, which appeared from the outside to be a kind of protection racket, was seen from the inside as legitimate recompense for the passage of strangers through tribal territories. It frequently broke down, with tribes attacking the caravans they had been paid to protect. ${ }^{50}$ Such breakdowns were recorded by local authorities and European travellers as resulting from the nomads' instinctive preference for loot over 
obligation, or even from some atavistic nomad savagery, but certainly other factors were operative. A failure to pay the agreed sums, either in part or in full, for example, might sour relations between merchants and tribes, leading the latter to take what they considered themselves to have been cheated of. From the mid-nineteenth century on, state-sponsored changes in landownership and the loss of customary rights of pasturage might also prompt dispossessed nomads to compensate themselves through attacks on formerly secure trade routes, even though these routes were guaranteed by their own chiefs and khans. Beduin robberies of pilgrims on the Hajj road were notorious, although the beduin tribes, or rather ther leaders, received subsidies from the Ottoman government to discourage raiding. The Ottoman sources were quick to attribute such robberies to a natural beduin inclination to crime. ${ }^{51}$ Yet again the subsidy system frequently broke down, the beduin then obliged to take what was necessary to their survival. ${ }^{52}$

Bandits of this kind originated from within peasant and pastoral communities, especially those with a tribal organization and they remained in varying degrees of contact with local populations. This contact might be very close and supportive, especially where ties of kin existed, but might also be deeply antagonistic and exploitative. Both nomadic and settled communities often gave succour to bandits, but, where succour was denied, the bandits' treatment of "hostile" villages might be extremely brutal. To some extent, Hobsbawm's distinction between nomadic raiding and banditry proper breaks down in the Middle Eastern context, the boundaries between nomads and peasants often fluid and permeable. Settled cultivators might be recently sedentarized former nomads, communities might be mixed cultivators and pastoralists, and peasants and nomads linked by tribal ties. Thus it is possible to see certain instances of nomadic raiding not as a phenomenon necessarily disconnected from and hostile to peasant life, but rather as an aspect of peasant economic activity, hardship and perhaps discontent. On the other hand, however, although they did not necessarily divide nomad from peasant, tribal ties might nonetheless impede as much as augment wider geographical or class-based bonds of solidarity, their privileging of vertical hierarchies and their fostering of inter-tribal violence often fatal to sustained rebellion.

Banditry has therefore been significant in both peasant and pastoralist strategies of survival in the Middle East and North Africa. This does not necessarily imply the presence of permanent bandit gangs. For many rural communities, a resort to banditry might not imply a way of life, involving an irreversible departure from peasant or pastoral origins, but might rather be a temporary activity, taken up in times of hardship and abandoned when the hardship passed, or might be seasonal or part-time, engaged in to supplement the inadequate rewards of agricultural or pastoral labour. Banditry might also be a strategy of the socially excluded, the marginal and the desperate, those with nothing to lose. Nineteenth century Morocco gives us many stories of fugitive slaves becoming highway robbers. The escaped slave Bilal, for example, gathered a band around him and pillaged travellers, moving from one tribe's territory to another whenever he felt threatened, his career lasting ten years. Other slaves operated in both northern and southern Morocco, always, interestingly, in association with free people. ${ }^{53}$ Such slaves typically became bandits after some interruption to their slave career. Often having been bodyguards or otherwise familiar with weapons, they simply struck out on their own when opportunity offered. ${ }^{54}$ Another figure, more truly an outlaw than the peasant or nomad robber, was the military deserter, possessing the advantage of military knowledge and training and sometimes also weapons. Demobilized soldiers have perennially provided bandit material. Rapid and chaotic demobilization produced waves of Celalis in the seventeenth century Ottoman empire, while the imposition of modern conscription in the nineteenth and twentieth centuries created many fugitives from enlistment and especially 
deserters. Deserters might have any of a range of motives, political opposition, personal antagonism, a simple wish to avoid military service, the need to leave the army to return home for family reasons or even merely to help with the harvest. Once outside the law, the deserter often linked up with civilian bands of robbers. By the 1920s in countries where military service was considered a pillar of the new state, such as Iran and Turkey, the deserter, from both the gendarmerie and the army and with some military experience, had become a specific and serious threat to rural security. ${ }^{55}$

Middle Eastern banditry, like crime in general, is often assumed to have been not only endemic but unchanging, its supposedly final elimination a consequence of modernization in general and the successful creation of rural police forces or gendarmeries in particular. Yet is it possible, on the contrary, to detect in the Middle East and North Africa epidemics of banditry reflecting 'the disruption of an entire society, the rise of new classes and social structures, the resistance of entire communities or peoples against the destruction of its way of life'? ${ }^{56}$ A rise in the incidence of banditry is generally and naturally associated with an increase in rural immiseration and pauperization and periods of economic crisis, thus constituting a strategy of survival. But given the much greater availability of source material, the late nineteenth and early twentieth centuries seem to demonstrate not only an increase in banditry but to suggest that this increase may be a direct consequence of, and form of resistance to, accelerating political and economic change, sometimes called modernization, including political centralization and the development of capitalism and its penetration into the rural areas.

The late nineteenth/early twentieth century Middle East certainly possessed the two conditions proposed as necessary for the emergence of social banditry: class conflict producing communal solidarity in the countryside, and an absence of institutionalized mechanisms such as political parties and peasant unions, for expressing and managing this conflict. ${ }^{57}$ The rapid commercialization of agriculture as the region was drawn into the global economy, the resulting criminalization of customary rights to the land for peasants and to pasturage for nomads producing dispossession and impoverishment in the countryside combined with authoritarian political systems, whether colonial or independent, to deprive the rural poor of viable alternatives to illegality.

The connection between modernization and banditry has been concretized in relation to late nineteenth century Ottoman statebuilding. The Ottoman road-building programme, for example, was intended to improve security, enhance trade and knit the empire together. The new roads, however, were not only an instrument of state power, but also provided space and opportunity for contesting that power. ${ }^{58}$ Not only were the new roads a product of Ottoman modernization, but so too were the highway robbers who infested them. These robbers included a variety of fugitives from new state institutions and policies, nomads fleeing compulsory sedentarization, peasants forced off the land by the spread of private ownership and impoverished by the commercialization of agriculture, rogue gendarmes, deserters from the army and evaders of conscription. In Egypt too, an increase in banditry seems to have resulted from similar changes initiated by the khedivial state, the collapse of the older subsistence economy and its replacement by production of cash crops grown for export, rural indebtedness, and the ever heavier hand of the state itself, with its demands for service in the army and forced labour. Organic connections between peasant resistance and banditry in the new Turkish republic, for example, may be discerned in the low-level violence endemic in the rural areas during the interwar period. Such violence was a last resort of the peasantry in the face of social and economic crisis and state policies, this violence taking the form of 
individual attacks on tax officials, gendarmes, village headmen, moneylenders, and the violation of the property rights of landowners and monopoly companies. ${ }^{59}$

The contemporary period in Iran saw the introduction of similar policies with similar results. Here too a determined assault on the way of life of the rural poor had begun in the nineteenth century with the twin processes of the integration of Iran into the global economy and the deepening penetration of capitalist relations into the countryside. In 1927 the newlyconsolidated Iranian monarchy launched an accelerated programme of unprecedented legislative radicalism, introducing a number of measures, conscription, land laws leading to the loss of customary cultivation and pasturage rights, dress laws aimed at the destruction of tribal culture, nomadic settlement and monopolies on opium and tobacco production, which had an immediate and devastating impact on the rural population, both peasants and pastoralists. The results were exactly the proliferation of outrages identified by Guha as precursors of rebellion in India, successive waves of rural violence which began in the mid1920s with increasing lawlessness and robbery, duly reaching a crescendo in 1929 with outbreaks across the country of nomad and peasant risings of an intensity which threatened the very survival of the regime. After the suppression of these risings, the rural areas reverted to lawlessness and banditry, serious insecurity continuing for several years. At the core of this violence were rebellions by the still armed and mobile nomadic tribes, accompanied by peasant discontent, many peasants in fact sedentarized former pastoralists with tribal links to the nomads. Widespread banditry was also an integral feature of these uprisings, again by elements with tribal connections. The actions of the tribal insurgents and bandit gangs were indistinguishable, as indeed were the two groups themselves, but both occasionally displayed a striking sensitivity to their wider base of support worthy of a social bandit. For example, the opium monopoly, which drastically reduced the income from poppy cultivation, had been the state policy, above all others, which had unified the opposition of the disparate elements of the rural poor across southern Iran. When tribal rebels took control of a small town in eastern Fars, they drove out the government officials and took possession of the government stores of opium. They then returned the opium to the cultivators for sale on the open market, less ten per cent, the equivalent of the government tax, which they kept for themselves. A similar story came from further north, in the region of Isfahan. Here one of the largest bandit gangs, together with tribal rebels, again captured the government opium store, took out the government percentage of ten per cent, and returned the remainder to the peasants, taking receipts. ${ }^{60}$

In the late nineteenth-early twentieth century, modernization, as well as stimulating banditry, also produced modernized types of crime, and led to further innovations in the panoply of subaltern avoidance and resistance. As new states consolidated their control over national territories, imposed controls and taxes on the movement of goods and people, and established borders of theoretical and legal impermeability, smuggling erupted on a massive scale. Across the Middle East and North Africa, as elsewhere, smuggling and banditry were closely allied, bandits engaging in smuggling and vice versa. Both, but especially smuggling, were directly related to state policies. Wherever restrictions were imposed, and especially where those restrictions were deemed illegitimate, individuals and entire communities devised ways of evading them.

Smuggling, like banditry, might be a means of survival in hard times, an economic opportunity, or a form of resistance to authority. The outbreak of a veritable war in the late Ottoman empire between a French-owned tobacco company with a newly-granted monopoly, the Régie, and local growers abetted by smuggling rings, demonstrates the presence of all 
three motives. ${ }^{61}$ For the professional and well-organized smuggling rings, the Régie's efforts to control the production and sale of tobacco represented an opportunity to make fortunes, perhaps as much as half the tobacco grown escaping Régie control. ${ }^{62}$ For the peasant cultivators, smuggling became a way of compensating for the reduced income resulting from the operation of the monopoly. Selling to smugglers also meant avoiding the government taxes and, if the cultivator was a sharecropper, handing over any portion to the landlord. ${ }^{63}$ It was not only the producers who were complicit in the smuggling, but consumers also, who willingly purchased tobacco from smugglers going from door to door in villages. Even representatives of the Ottoman state, officials and gendarmes, turned a blind eye to smuggling, or even participated in it.

For the peasant cultivators, smuggling was a strategy of both survival and resistance. But its success depended on its being embedded in a sympathetic environment where it was widely perceived as legitimate and even, insofar as it hampered and frustrated the Régie, as a social good. The general population and even the Ottoman government itself resented the encroachment on sovereignty represented by the increasing foreign presence throughout the empire and the Régie's lack of legitimacy contributed to a general readiness by wide layers of Ottoman society to evade and resist the company's monopoly.

Smuggling was a covert, but very effective, means of undermining the Régie. It was one aspect of a broader struggle against the monopoly which combined legal and recognized traditions of protest, such as demonstrations and presenting petitions to the Sultan, with violent defiance, rioting and stoning Régie offices, and attacks on Régie troops. ${ }^{64}$ The struggle between the Régie and the smugglers was indeed both bitter and violent. According to one Ottoman report, in the first fourteen years of the company's operation, not less than two thousand people every year had lost their lives in this struggle. ${ }^{65}$ Such resistance harried the operations of the Régie on the ground but it failed to offer any broader challenge to the continuation of the foreign monopoly. It remained scattered and sporadic, confined to the countryside and small towns, and almost completely subaltern in character. Its limitations are revealed by its contrast to neighbouring Iran, where a mass urban movement led by a powerful coalition of ulama, merchants and reformist intellectuals forced the cancellation of a similar tobacco monopoly, it never attracted consistent elite support. Although the Régie strained every nerve to suppress the illegal trade, in the end the company learned to live with it and the Ottoman government to live with the company. The Régie survived all the vicissitudes of revolution and war until it was finally nationalized by the new Turkish republic in 1925, the Kemalist authorities ejecting foreign control but retaining a monopoly as part of their etatiste economic policies. The smuggling continued.

Mot smuggling was not, of course, either on the scale, nor possessing the overt political significance of the Ottoman tobacco war. Nonetheless, smuggling everywhere, like banditry but perhaps to an even greater extent, required the active collaboration of elements among the larger local community. Both, but again especially smuggling, were extremely difficult to suppress. Prescribed penalties might be severe but their application depended on apprehending the elusive malefactors. Since proof against the accused, and even the accused themselves, might be hard to find, the authorities often resorted to collective punishments, fixing blame on villages in the vicinity of the crime, local peasants being ready scapegoats. ${ }^{66}$ Subsequent scholarship might debate the existence and character of the relationship between bandits and peasants but the Ottoman authorities were in no doubt regarding their mutually supportive links. In Iran too collective punishment, especially against nomads in the form of 
the authorized plundering of tents, was common, and often resulted in the generation of further banditry by the impoverished and vengeful tribal communities. ${ }^{67}$

Both banditry and smuggling might also be carried out at sea as well as on land and contemporary authorities made a similar assumption about the existence of close and friendly connections between local coastal communities and sea-bandits or pirates. Villagers might provide pirates, who prowled along the coast, waited and watched just outside harbours and hid in coves and bays, with news of approaching ships, as well as food and shelter. ${ }^{6}$ One example comes from the early eighteenth century when an Ottoman court ruled that local villagers on the Aegean coast must recompense the owner of a tobacco shipment looted by pirates as it had been proved that one of the villagers had passed information about the cargo to the pirates. As not only the pirates themselves, but even the villager who has alerted them escaped, it was the remaining villagers who paid the price. ${ }^{69}$

As in the case of land banditry, both scholarly and popular interest in sea-banditry, especially in the Mediterranean, has adopted an elite perspective. Regarding the Barbary corsairs in the western Mediterranean from the sixteenth to the early nineteenth century, for example, we know a great deal of their place in interstate relations, in naval warfare, and the strategic, economic, and legal dimensions of their activities, of corsairing's role in the slave trade and Muslim-Christian relations as seen through the prism of the ransoming of captives. ${ }^{70}$ Of the pirates or corsairs themselves, however, and of pirate crews, we know very little. This is in stark contrast to our knowledge of the "Golden Age" of Atlantic piracy in the late seventeenth-early eighteenth century where we find studies both of the lives of individual pirates and of piracy as a collective response to the brutalities of naval life. ${ }^{71}$

Yet corsairing in the western Mediterranean, both Muslim and Christian, may also be approached from a subaltern direction, tracing not only the macro-economic and political roles of the corsairs, but also something of their background, their motivation and the character of their activities. The Barbary corsairs, from the point of view of their own societies, seem to resemble very closely Hobsbawm's “avenger.” Indeed, as kursan they are quite clearly differentiated in Arabic from ordinary sea-robber (liss al-bahr). The Barbary corsairs were the sea-borne counterparts of the Morisco bandits of sixteenth century Andalusia. At the beginning of the seventeenth century, Spain had begun the mass expulsion of the Moriscos, Spanish Muslims who had converted to Christianity after the Reconquista but who remained objects of suspicion. The numbers deported by ship and abandoned on North African shores amounted to at least half a million, and possibly many more. Hundreds of thousands of these Moriscos settled where they had been forced to disembark from the Spanish galleys, in North African coastal towns. Dispossessed and exiled, they devoted themselves to harrying their former compatriots, launching what became known in Arabic sources as a sea-borne jihad, the corsairs described by Arabic sources as ghazi (religious warrior). The "Corsair Republic" of the port of Salé was populated largely by expelled Moriscos, some of whom became famous. These corsairs found representation in elite biographical and polemical literature, but also in popular poetry and song, where they took on the quality of Hobsbawm's avenger, memorializing injustice and offering hope of retaliation. $^{72}$

The phenomenon of the Barbary corsairs, so terrifying to early modern Europe, may thus be related directly to the catastrophe which befell the Spanish Moriscos and their individual and collective strategies of revenge and compensation. In general, major waves of piracy, like banditry, were not a perennial and random hazard but rather arose from social dislocation and 
military conflict. As Celalis were produced by the military mobilizations of the seventeenth century, and swarms of deserters by twentieth century conscription, so pirates proliferated in times of, and especially after the end of, large-scale naval conflict. The Mediterranean east of Malta, for example, witnessed an explosion of Greek piracy in the 1820s linked to the Greek war of independence. Again, these Greek pirates may be seen as the exact counterparts of the mainland klephts and were romanticized accordingly, by both Greek nationalists and philhellenic sentiment in Western Europe.

Corsairing, like certain types of banditry, was an integral element of pre-modern local and regional economies throughout the Mediterranean, Christian as well as Muslim, both sides combining material benefit with religious justification. It was distinguished, at least theoretically, from piracy proper by the stipulation that its legitimacy depended on its being carried out under the auspices of a recognized authority, who shared by right in the booty. ${ }^{73}$

In practice corsairing activity exactly resembled piracy, the only distinction being the formal possession of the patronage of a recognized ruler. It was thus extremely easy, and almost inevitable when times were hard, for legitimate corsairs to turn into pirates. Maltese seamen, for example, accumulated centuries of experience under the patronage of the Knights of Malta. ${ }^{74}$ Although their activities were theoretically limited to the traditional enemies of Christianity, Maltese corsairs would often, when legitimate prey ran short, close their eye 'to the fussy terms of their letter of marque', and attack friendly and unfriendly shipping alike, even though this actually turned them into pirates, subject to the death penalty. ${ }^{75}$ When corsairing was legally abolished at the end of the eighteenth century, these coastal communities were left without the means of making a legitimate living. Many complied with the new legal prohibition, some ceased corsairing but took up other sea-borne crime, especially smuggling, some emigrated to North Africa taking their skills with them, and some simply continued as before, their activities now purely criminal. Many narratives of their activities, their capture and their fates may be found in the archives of the Vice-Admiralty Court established in Malta by the British.

Sea-banditry or piracy and smuggling were closely connected and were as endemic to the waters of the Middle East and North Africa as robbery was to the land. Just as pastoral nomadism lent itself easily to banditry, so the economic activities of coastal communities, fishing and sea-faring, might similarly slide, almost imperceptibly, into illegality, smuggling and sea-banditry. Mediterranean piracy was often on a small scale, the crews made up of ordinary fishermen or local seamen, their vessels small boats powered by oars, ${ }^{76}$ the picture they presented far from the images of galleons armed with cannon familiar from the popular imagination of Caribbean piracy. $\mathrm{N}$ this sense they may also be seen as connected to peasant strategies of survival and resistance. Towns along the North African coast, for example, which had earlier played a role in the corsair economies, seem to have adapted to sea-borne smuggling particularly easily. ${ }^{77}$

Sea-banditry or piracy and smuggling in the eastern Mediterranean also allow a glimpse of the smugglers and pirates themselves. To some extent, outlaw life offered an inherent challenge to existing hierarchies. The little that we know of the precise composition of Middle Eastern and North African bandit gangs or pirate crews seems to indicate the fluidity of social, religious and ethnic boundaries officially depicted, as rigid and impermeable. This may hint at the irrelevance of these boundaries to those sharing outlaw status, or perhaps at a deliberate challenge to convention, or it may be evidence of an actual plebeian indifference to and disregard of such boundaries typical of lower class life. Marinos Sariyannis has noted the 
remarkably mixed religious and ethnic character of urban criminal gangs in seventeenth century Istanbul and the linguistically and religiously mixed pirate crews. ${ }^{78}$ Although Andalusian exiles were a dominant force in Barbary corsairing, a single crew might include not only Spanish and Moroccan Muslims but also renegades and Christians, Greeks, Russians, French, Dutch and so on. ${ }^{79}$ They were indeed motley crews. Piracy even appear to offered opportunities for, or at least held out the hope of, rapid changes in individual fortune, even a kind of social mobility, an Ottoman pirate novel of the late seventeenth century, a rare surviving specimen of popular literature, telling the tale of a slave becoming a pirate commander. ${ }^{80}$

The case of North Africa also highlights particularly the connections between Christian and Muslim subalterns in the nexus of extra-legal seaborne activities. Malta, as a result of its earlier role as a hub of corsairing and piracy, had become by the nineteenth century the centre of Mediterranean smuggling, of slaves (after the abolition of the trade), weapons and gunpowder, tobacco and spirits, and the Maltese its principal practitioners. ${ }^{81}$ Poor European migrants settled in the port cities, especially the experienced and extensively networked Maltese, played a key role in connecting Mediterranean suppliers of smuggled commodities with the North African interior, such smuggling again usually on a small, domestic scale with women closely involved in the hiding and selling of goods. ${ }^{82}$

What we know of pre-modern, and even modern, Middle Eastern land and sea bandits, comes from two quite separate and contradictory categories of sources, on the one hand official reports, court records and the rarely independent and always elite press, on the other hand folk stories, poems and songs. The former invariably emphasize the anarchic violence of bandits and their threat to life and property, primarily of the rich although peasant suffering is also sometimes mobilized. Folk stories and songs, on the other hand, conform very closely to their cultural counterparts elsewhere, making sense of the bandit phenomenon from the point of view of those at variance with the prevailing political, social and economic order, turning the bandit sometimes into a picaresque hero triumphing over the authorities against the odds, sometimes into an avenger of injustice. Much attention has focused on trying to explain these contradictory narratives and to reconciling them, in other words to establishing the "truth" about bandit activities. But it is perhaps more useful to regard them as symptomatic of fundamentally opposed worldviews, of those who prospered under the status quo, and those who did not. Rather than reconciling them, they might be decoded, to glimpse, not an accurate picture of what bandits did, but rather how the lower classes perceived them and, perhaps more importantly, how the lower classes perceived the authorities, the common enemies of themselves and the bandits.

To what extent, then, does Middle Eastern folk culture really allow us access to the subaltern psychological world? Despite the reinvention of bandits by Balkan nationalists and Turkish Marxists, it seems that much Middle Eastern popular bandit mythology has genuinely popular origins. The folk tales emerged and crystallized within an oral tradition. They were spread by professional story-tellers who were free to improvise, thus shaping their narratives in response to the demands of their audiences. More generally, popular attitudes towards authority and legitimacy, justice and resistance, are crucial to understanding the ways in which bandit narratives were constructed and incorporated into popular discourses. Folk stories often contained an element of rudimentary class consciousness, contrasting a worthless and stupid king with a poor man seeking justice and true happiness, concluding with the triumph of the latter. ${ }^{83}$ Hints at subaltern subversions of elite notions of crime and criminality may be found in Ottoman folk stories in which crimes are frequent but any sort of 
disapproval rare. ${ }^{84}$ Executed robbers might find admiration from the poor of Istanbul because of their 'manliness and gallantry', and there seems to have been some popular sympathy for prisoners and attacks on jails were common features of Istanbul revolts. ${ }^{85}$

Many of the admirable traits bestowed by folklore on the bandit-hero may be traced to a broader popular cultural consensus, reinforced by the glamour of the picaresque and local codes of honour and masculinity. This combination of attitudes may be seen very powerfully in an urban context in relation to the qabadayat of Ottoman cities, the Iranian lutis, and the Egyptian baltagiya. ${ }^{86}$ These well-organized gangs of young men, illiterate and drawn from the urban poor were important features of pre-modern Middle Eastern cities. ${ }^{87}$ Both their actual activities and attitudes towards them recall the social bandit story. Physical strength and courage, "manliness," were vital to the gangmember, as was honour, and a reputation for being ready to defend it with violence, on his own behalf, that of his quarter, and sometimes of the vaguely defined oppressed in general. ${ }^{88}$ A code of chivalry was important, and the protection of women and children emphasized. Attitudes towards these gangs were as varied as towards bandits. Elite descriptions stress their thievery, idleness and troublemaking, while their own self-image seems to have been largely accepted and perpetuated by the urban poor, from whose ranks they were drawn, although even here they retained their marginal, even sometimes deviant, status. Although often posing as popular leaders of their quarter, many gangs also had actual connections to local notables and especially to religious figures, for whom they would provide muscle in conflicts, with other urban quarters, hostile notables or the government.

Such gangs had no necessary political inclination or affiliation. Lutis, for example, were to be found on both sides during the Iranian constitutional revolution. ${ }^{89}$ Although their plebeian origins and their self-proclaimed role as defenders of the poor might appear to make them candidates for the patronage of the Left, in fact during the twentieth century the links between the gangs and political tendencies of a more or less reactionary character became more overt, and the gaps between gang mythology and the actual roles they played became wider, the similarities with Anton Blok's mafia emerging more strongly. Lutis were key mobilizers of the crowd which provided support on the Tehran streets for the overthrow in 1953 of the nationalist prime minister Dr Muhammad Musaddiq, and even more recently the Egyptian baltagiya were identified as the prime instigators of the violence against anti-Mubarak protesters in Tahrir Square during the Egyptian uprising in 2011.

Such bandit biographies as have emerged in the Middle East and North Africa must then be read within the context of these pre-existing scripts. One of the earliest and most famous bandit-heroes whose actual existence is more or less certain is the sixteenth century Ottoman Koroglu. The Ottoman records make it difficult to distinguish his social banditry from his straightforward robbery, but it seems that he either actually did, or quickly attracted a reputation for, attacking officials singled out as oppressors of the poor. ${ }^{90}$ Within a generation, Koroglu had become a favourite subject of story-telling, transformed from a coarse but amusing trickster into an avenger against tyranny. Commemorated in verse as 'the people's sword', he became a hero, reputedly calling on the peasants to take up arms against the sultan in the quest for justice. ${ }^{91}$

More recent history allows the contours of bandit figures to emerge somewhat more reliably. The French colonial presence in North Africa, like foreign domination elsewhere, appears to have provided particularly fertile ground for the emergence of social bandit legends, the colonial authorities and the local populations having a mutual interest in the manufacture of 
bandit stories. While colonial or imperial authority labelled resistance as banditry, local opinion appropriated banditry as resistance.

A wave of banditry, or at least violence, swept the Algerian countryside following the 1871 uprising in Kabylia, a mountainous coastal region in the north of the country, and its suppression by the French. It flared up again in the 1880s-90s, producing the famous story of Muhammad Abdun. ${ }^{92}$ Unjustly accused of murder and imprisoned on Devils' Island, Muhammad Abdun escaped and, after a series of extraordinary adventures, returned to exact vengeance. Whether the local population supported Abdun or merely feared him is unclear, nor can his robbery be easily distinguished from his rebelliousness, but his activities led to a spreading attitude of non-cooperation with the French authorities, especially a refusal to pay taxes or to accept office as French-appointed village headmen or to join the police. The French certainly believed themselves to be facing the beginnings of a revolt and responded accordingly.

A neghbouring region of Algeria produced the better-known 'bandit of honour' Messaoud Ben Zelmat, active in the Aurès beween 1917 and1921. ${ }^{93}$ The story begins in 1915 when Ali Ben Zelmat, a shepherd, was denounced for theft and sentenced to prison, escaped, returned to kill the man who denounced him and then took to the forest. He joined a group of army deserters and they established themselves in the mountains. In 1917, after government forces attacked the band, Ali was found dead. His brother, Messaoud, took command of the remnants of the band and vowed to avenge his brother, and he and his men carried out a series of robberies and murders. operations took place within a context of serious local tension. The World War, in which the Ottomans and French were on opposing sides, was unpopular, and conscription into the French army was especially hated and resisted, a situation which gave Messaoud Ben Zelmat's activities a sheen of political significance and genuine local support and even admiration. According to a report by a French gendarmerie officer, the bandits were able to rely on local people for everything they wanted, food, ammunition, shelter and information. ${ }^{94}$ Eventually Messaoud Ben Zelmat's luck ran out and, betrayed by local shepherds, in 1921 he was killed by native Algerian soldiers.

Massaoud Ben Zelmat's reputation rests on two local sources, songs sung by local women, and the reminiscences of a rather marginal European who had befriended him, Jean-Baptiste Capeletti, this material shaped into a story of social banditry, although not national resistance, in an article by Jean Déjeux. Capeletti had spent most of his long life in the Aurès mountains, where he made a living as a miller and married a local Berber woman. In 1975, at the age of one hundred, Capeletti gave a description of his great friend, Messaoud Ben Zelmat, bestowing on him the title of a bandit of honour, whose main aim was to protected the 'little people' against the local notables who exploited the poor and weak, Capaletti confirming both Messaoud's popularity among his own people and the fear in which he was held by the army and especially by the notables. ${ }^{95}$ Another important element in the creation of the Messaoud legend was the repertoire of songs composed about him and sung by local women. Using the imagery of love poetry, these songs celebrated Messaoud's bravery, chivalry, generosity, protection of the poor, and contempt for material possessions. Conforming closely to generic bandit narratives, the songs marvel at his miraculous powers and mourn his death through betrayal, using poetic conventions to incorporate Messaoud into widely shared folk traditions. ${ }^{96}$

Messaoud Ben Zelmat, however, remained a figure of only local legend, and was never incorporated into the genealogy of Algerian nationalism. Indeed Middle Eastern and North 
African Zapatas are rare. Iran, however, does provide one example of a bandit turned revolutionary who still occupies an important place in collective memories of the popular struggle for justice. ${ }^{97}$ Sattar Khan was a one-time bandit and luti who became a renowned fighter in the constitutional revolution of early twentieth century Iran. Sattar's reputation, still alive and fostered in the Islamic republic, is largely the result of the work of populist Iranian intellectuals who have glorified him and his activities, this perspective triumphing over that of elitist historians writing in the Pahlavi period who have been much more sceptical, insisting on his being nothing more than a bandit. ${ }^{98}$ Born in 1868 , Sattar's youth included periods of imprisonment punctuated by both brigandage, in which trade he followed his elder brother who had been executed, and service in the local gendarmerie. Sympathetic biographers, however, subsequently provided him with a version of his early life more appropriate to a luti as a righteous, if violent, defender of the oppressed. The constitutional revolution which broke out in Iran in 1905, and especially the civil war of 1908-9 between constitutionalists and supporters of the shah, which centred on Sattar's home, the northern city of Tabriz, gave him the opportunity to become a national figure and he became, and was recognized internationally as, a leading fighter of the constitutionalist forces. His is one of the earliest Middle Eastern examples of mythologizing through photography, images of him as the archetypal bandit-hero, draped in bandoliers, disseminated widely through the press and as postcards. Probably understanding little of the national political objectives of the constitutional movement, and possibly motivated by a desire for revenge against the authorities who had executed his brother, Sattar's new role was predicated on his luti background. His familiarity with weapons, his need to maintain his reputation for courage and manliness and his status as defender of his quarter, made him a natural militia leader and he soon came to be credited by local opinion with the possession of magical powers, the protection of a saint and invulnerability to bullets. ${ }^{99}$ Perhaps more Pancho Villa than Zapata, Sattar's later political failures and personal weaknesses, much in evidence after the constitutionalist victory, did nothing to tarnish his reputation, rather his humble origins, his illiteracy, his reputation for piety (deserved or not) and as a defender of the poor, made him an icon for the revolutionary movement of the 1970s.

The Middle East and North Africa has experienced every type of banditry imaginable. It has seen bandit-kings and warlords presiding over extensive raiding networks, entire communities, Turkish and Iranian nomads, desert beduin, integrating banditry and smuggling as essential elements into their precarious local economies, "everyday” banditry as a last resort of pauperized peasants and pastoralists in the face of economic catastrophe and social marginalization, banditry as a form of rural resistance and even, occasionally, bandits as revolutionaries. Banditry on land and sea has occupied a key place in elite discourses and has also spawned a vast repertoire of popular iconography, these contrasting and entirely irreconcilable interpretations revealing an often submerged but perennial ideological war between state and subaltern. If Robin Hood has been hard to find on the ground, the avenger has exercised an extraordinary power over the popular imagination.

A widespread scepticism about the capacity of Middle Eastern peasantries for collective action, an inclination to interpret peasant violence as tribal or religious rather than economically-motivated and class-based, a lack of interest in peasant resistance, an outdated and unsophisticated methodological approach which privileges elite textual sources and takes little or no account of advances in oral history and memory studies, have combined to produce an emphasis in Middle Eastern scholarship on the relationship between bandits and the worlds of power. A different approach, however, provides different answers. In particular, close attention to the deconstruction of the language of existing elite sources, the 
semiotics of banditry, the adoption of a microhistorical perspective, and the incorporation of perspectives derived from non-elite sources, can tease out subaltern stories. In particular, the perspectives discernible within folk culture might be, not accepted uncritically but treated with equal seriousness to those found within state archives. Stories about bandits may be myths, but whose myths are they? Ballads and poems about Greek or Bulgarian haiduks may have been appropriated by local nationalist elites, but they were originally genuinely popular creations, produced by the rural communities themselves who clung to them. The songs about the Algerian 'bandit d'honneur', Messaoud Ben Zelmat, were sung by local women before they were picked up by French intellectuals, while the seventeenth century Anatolian bandit Koroglu achieved his fame across the Turkish and Persian-speaking worlds by oral repetition and popular shaping of the legends surrounding him.

Banditry has constantly reinvented itself in response to state policies and especially to modernization. In the classical sense it did decline across the Middle East and North Africa in the decades after the Second World War, as the peasantry itself shrank rapidly or found new, if muted, representation in radical regimes with programmes of land reform. Strong states, with powerful armies and gendarmeries and modern infrastructure, reduced the scope for rural crime while the 'mobile margin' of peasant society, ${ }^{100}$ disaffected young men, found opportunities in education and expanding economies and massive migration to the cities and abroad. Yet smuggling became more profitable than ever, and urban crime offered new opportunities, especially in the drug trade. ${ }^{101}$ Since the invasion of Iraq in 2003, banditry has indeed, together with its partners, smuggling and piracy, recently experienced a massive resurgence in the ungoverned spaces, on land and sea, created by the collapsing states of the modern Middle East and North Africa. In many of the countries of the region, militias now occupy the ambiguous space once filled by bandits. Just as demobilized Ottoman soldiers of the seventeenth century joined bandit gangs, so Iraqi troops, suddenly turned out after the US invasion of 2003, provided much of the personnel for the mushrooming militias. The metalanguage of terrorism now obscures a complex reality, as did once a similar meta-language of banditry. Vast fortunes are being made smuggling the same commodities as in the nineteenth century: cigarettes and drugs across the Sahara to North Africa and then into Europe, people across the Mediterranean and weapons everywhere. Piracy is now a multi-million dollar industry in the seas off the Horn of Africa, causing the cost of maritime insurance to rocket and, as in the seventeenth and eighteenth centuries so once again, people captured for ransom are as valuable as cargoes. Yet, in addition to the ruthless egoism of the people-smugglers of the Mediterranean, the contemporary Middle East also suggests instances of such activities as representative of political protest and resistance, the smugglers of the Gaza tunnels a striking example. Banditry, as economic opportunity, survival, and perhaps occasionally rebellion, is once again endemic across the region. 
The author is grateful to Roshan Cultural Heritage Institute and its President, Dr Elahé Omidyar Mir-Djalali, for funding the fellowship which enabled her to work on this article.

1 See, most notably, Yashar Kemal, Memed, My Hawk, translated by Edouard Roditi (London: Harvill Press, 1990).

2 The literature on social banditry, for and against, in these areas is very substantial. For Latin America, see, inter alia, Gilbert M. Joseph, 'On the Trail of Latin American Bandits: A Reexamination of Peasant Resistance', Latin American Research Review, vol.25, no.3, 1990, pp.7-53, and the subsequent debate in that journal. See also Richard W. Slatta (ed), Bandidos; the Varieties of Latin American Banditry. New York, London: Greenwood, 1987); On China see Patrick Fuliang Shan, 'Insecurity, Outlawry and Social Order: Banditry in China's Heilongjiang Frontier Region, 1900-1931', Journal of Social History, vol.40, no.1, 2006, pp.25-54; Robert J. Antony, 'Peasants, Heroes, and Brigands: The Problem of Social Banditry in Early Nineteenth-Century South China,' Modern China, vol.15, no.2, 1989, pp.123-148. Tibet is discussed by Tsering Shakya, 'Ga rgya 'gram nag: A bandit or protorebel? The question of banditry as social protest in Nag chu', Trails of the Tibetan Tradition: Papers for Elliot Sperling (Dharamshala: Amnye Machen Institute, 2014). For India, see David Arnold, 'Dacoity and Rural Crime in Madras, 1860-1940', Journal of Peasant Studies, vol.6, 1979, pp.140-167; Kim A. Wagner, 'Thuggee and Social Banditry Reconsidered', The Historical Journal, vol.50, no. 2, 2007, pp.353-376; for south-east Asia see Greg Bankoff, 'Bandits, Banditry and Landscapes of Crime in the Nineteenth-Century Phillipines', Journal of Southeast Asian Studies, vol.29, no.2, 1998, pp.319-39; Boon Kheng Cheah, The Peasant Robbers of Kedah, 1900-1919: Historical and Folk Perceptions (London, Singapore: Oxford University Press, 1988); For Africa, Allen Isaacman, 'Social Banditry in Zimbabwe (Rhodesia) and Mozambique, 1894-1907: An Expression of Early Peasant Protest', Journal of Southern African Studies, vol.4, no.1, 1977, pp.1-30. The literature on social banditry in Europe is very extensive. For a recent account, see Shingo Minamizuka, A Social Bandit in Nineteenth Century Hungary: Rósza Sándor (Boulder, C.: East European Monographs, 2008). 
$3 \quad$ Eric Hobsbawm, Bandits (London: Weidenfeld and Nicolson, 1969, 2000).

$4 \quad$ Stanley Cohen, 'Bandits, Rebels or Criminals: African History and Western Criminology’, Africa: Journal of the International African Institute, vol.56, no.4, 1986, pp.468-483.

Hobsbawm, Bandits, p.20.

Hobsbawm, Bandits, p.67.

See Joseph, 'On the Trail of Latin American Bandits', note, 41, p. 38; Anton Blok, The Mafia of a Sicilian Village, 1860-1960: A Study of Violent Peasant Entrepreneurs (Oxford: Basil Blackwell, 1974), note10, p.101.

8 Hobsbawm, Bandits, p.182.

$9 \quad$ Hobsbawm, Bandits, p.182.

10 Anton Blok, 'The Peasant and the Brigand: Social Banditry Reconsidered', Comparative Studies in Society and History, vol.14, no.4, 1972, pp.494-503.

11 Blok, 'The Peasant and the Brigand'. p.499.

12 Graham Seal, 'The Robin Hood Principle: Folklore, History and the Social Bandit', Journal of Folklore Research, vol.46, no.1, 2009, pp.67-89.

13 John S. Koliopoulos, Brigands with a Cause: Brigandage and Irredentism in Modern Greece, 1821-1912 (Clarendon Press: Oxford, 1987); Maria Todorova (ed), Balkan Identities: Nation and Memory (NYU Press: New York, 2004), p.21; Alice Blackwood, 'Criminal or Nationalist? The Social Purposes and Results of the Creation of a 'Social Bandit' Mythos in the Balkans', Balkan Folklore, pp.1-11.

14 Tomas Balkelis, 'Social Banditry and Nation-Making: The Myth of a Lithuanian Robber', Past and Present, no.198, 2008, pp.111-145.

15 See Seal, 'The Robin Hood Principle'.

16 Ranajit Guha, Elementary Aspects of Peasant Insurgency in Colonial India (Foreword by James Scott), (Durham and London: Duke University Press, 1999), p.91

17 Guha, Elementary Aspects of Peasant Insurgency, p.83.

18 Guha, Elementary Aspects of Peasant Insurgency, p.93; Joseph, 'On the Trail of Latin American Bandits’, pp.20-2.

19 For a full discussion, see Joseph, 'On the Trail of Latin American Bandits'.

20 Joseph, 'On the Trail of Latin American Bandits', pp.34-5.

21 Donald Crummey, 'Introduction: “The Great Beast”', Donald Crummey (ed)

Banditry, Rebellion and Social Protest in Africa (London: Currey, 1986), p.12.

22 For bandit biographies and (semi-)autobiographies, see for example, Billy Jaynes Chandler, The Bandit King: Lampiao of Brazil (Texas A\&M University Press: Texas, 1978); Phoolan Devi with Marie-Therese Cuny and Paul Rambali, I, Phoolan Devi:

The Autobiography of India's Bandit Queen (Little, Brown and Company: New York, 1996).

23 Such incorporation has been important in assisting the collection of material. See for example the assiduous research carried out under official auspices in China into the bandit Bai Lang and his movement. Elizabeth J. Perry, 'Social Banditry Revisited: The Case of Bai Lang, a Chinese Brigand', Modern China, vol.9, no.3, 1983, pp.355-382, note3, p.379.

24 Ted Swedenburg, Memories of Revolt: The 1936-1939 Rebellion and the Palestinian National Past (Minneapolis: University of Minnesota Press, 1995), p. 94-6.

$25 \quad$ Nathan Brown, 'Brigands and State Building: The Invention of Banditry in Modern Egypt', Comparative Studies in Society and History, vol.32, no.2, 1990, pp.258-281; Karen Barkey, Bandits and Bureaucrats: The Ottoman Route to State Centralization (New York, Ithaca: Cornell University Press: 1994).

26 Brown, 'Brigands and State Building', p.263. 
This account is drawn from Brown, 'Brigands and State Building'

Barkey, Bandits and Bureaucrats. The notion of a generalized crisis of the seventeenth century was first proposed by Eric Hobsbawm in two articles published in Past and Present in 1954. For a recent assessment of the state of the debate and the literature thus generated see the articles collected in the American Historical Review, vol.120, issue 4, October 2015. Barkey, Bandits and Bureaucrats.

30 David M. Hart, Banditry in Islam: Case studies from Morocco, Algeria and the Pakistan North West Frontier (Wisbech: Menas Press, 1987), p.7. Such strategies were not confined to the Middle East and North Africa. Indeed the "poacher turned gamekeeper” is probably a universal phenomenon.

$31 \quad$ Hart, Banditry in Islam, pp.19-26.

32 This account of is drawn from Andrew G. Gould, 'Lords or Bandits? The Derebeys of Cilicia', International Journal of Middle East Studies, vol.7, no.4, 1976, pp.485-506. 33 Gould, 'Lords or Bandits?'

$34 \quad$ Barkey, Bandits and Bureaucrats, p.9.

35 Barkey, Bandits and Bureaucrats, p.86. The supposed absence of peasant rebellion has been theorized. See Farhad Kazemi and Evand Abrahamian, 'The Nonrevolutionary Peasantry of Modern Iran', Iranian Studies, vol.11, no.1, 1978, pp.259-304. For a discussion of form of peasant resistance in Egypt see Nathan Brown, Peasant Politics in Modern Egypt: The Struggle Against the State (New Haven: Yale University Press, 1990).

$36 \quad$ Ibn Khaldun, The Muqaddimah: An Introduction to History, (eds) N. J. Dawood, Franz Rosenthal (London: Routledge and Kegan Paul in association with Secker and Warburg, 1967).

37 Brown, 'Brigands and State Building', p.260.

38 Barkey, Bandits and Bureaucrats, pp.153-4.

39 For a discussion of this vocabulary see Marinos Sariyannis, “Mob”, "Scamps” and Rebels in Sevententh Century Istanbul: Some Remarks on Ottoman Social Vocabulary', International Journal of Turkish Studies, vol.11, nos.1-2, 2005, pp.1-15; Leslie Peirce, 'Abduction with (Dis)honor: Sovereigns, Brigands, and Heroes in the Ottoman World', Journal of Early Modern History, vol.15, 2001, pp.311-329, p.320.

$40 \quad$ Faroqui, Coping with the State, pp.148.

41 Swedenburg, Memories of Revolt, p.94-6.

$42 \quad$ Hart, Banditry in Islam, pp.2-3.

43 David Prochaska, 'Fire on the mountain: resisting colonialism in Algeria', Donald Crummey (ed) Banditry, Rebellion and Social Protest in Africa, pp.229-252.

$44 \quad$ This account is drawn from Prochaska, 'Fire on the mountain'.

45 Prochaska, 'Fire on the mountain', pp.231-3

46 Prochaska, 'Fire on the mountain', p.237

47 Prochaska, 'Fire on the mountain', pp.239-47.

$48 \quad$ Ellis Goldberg, 'Peasants in Revolt - Egypt 1919', International Journal of Middle East Studies, vol.24, no.2, 1992, pp.261-280.

49 Touraj Atabaki and Eric J. Zurcher (eds), Men of Order : authoritarian modernization under Atatürk and Reza Shah (London : I.B. Tauris, 2003).

$50 \quad$ Fulya Ozkan, 'Gravediggers of the Modern State: Highway Robbers on the TrabzonBayezid Road, 1850s-1910s', Journal of Persianate Studies, vol.7, No.2, 2014, p.225.

$51 \quad$ Faroqui, Coping with the State, p.183.

52 Faroqui, Coping with the State, p.182. For a most enlightening study of Ottoman "colonial” attitudes towards the peoples of its own periphery, see Selim Derengil, “ "They 
Live in a State of Nomadism and Savagery": The Late Ottoman Empire and the Post-Colonial Debate', Comparative Studies in Society and History, vol.45, no.2, 2003, pp.311-342.

$53 \quad$ Mohammed Ennaji, Serving the Master: Slavery and Society in Nineteenth-Century Morocco, trans. Seth Graebner (Basingstoke: Macmillan, 1999), p.50.

54 Ennaji, Serving the Master, pp.49-51.

55 For an account of one such deserter, see Stephanie Cronin, Tribal Politics in Iran: Rural Conflict and the New State, 1921-1941 (Abingdon: Routledge, 2007), pp.107. $56 \quad$ Hobsbawm, Bandits, p.27.

57 Pat O’Malley, 'Class Conflict, Land and Social Banditry: Bushranging in Nineteenth Century Australia’, Social Problems, vol.26, no.3, 1979, pp.271-283.

$58 \quad$ Ozkan, 'Gravediggers of the Modern State', p.225.

59 Personal communication. I am grateful to Murat Metinsoy for this information.

60 Cronin, Tribal Politics in Iran, p.128

61 This account is drawn from Donald Quataert, 'The Régie, Smugglers and the Government', Social Disintegration and Popular Resistance in the Ottoman Empire, 18811908, Reactions to European Economic Penetration (New York and London: New York University Press, 1983).

62 Quataert, 'The Régie, Smugglers and the Government', p.21.

63 Quataert, 'The Régie, Smugglers and the Government', pp.24.

64 Quataert, 'The Régie, Smugglers and the Government', p.20.

65 Quataert, 'The Régie, Smugglers and the Government', p.34.

66 Ozkan, 'Gravediggers of the Modern State', p.244.

67 Mansoureh Ettehadieh (Nezam-Mafie), 'Crime, security and insecurity: sociopolitical conditions of Iran, 1875-1924', Roxane Farmanfarmaian (ed), War and Peace in Qajar Persia: Implications Past and Present (Abingdon: Routledge, 2008), p.179.

$68 \quad$ Eyal Ginio, 'Piracy and Redemption in the Aegean Sea during the First Half of the Eighteenth Century', Turcica, vol.33, 2001, pp.137-8.

69 Ginio, 'Piracy and Redemption', pp.137-8.

70 See, for example, Alan G. Jamieson, Lords of the Sea: A History of the Barbary Corsairs (London: Reaktion Books, 2012); Catherine Wendy Bracewell, The Uskoks of Senj: Piracy, Banditry, and Holy War in the Sixteenth-Century Adriatic (Ithaca: Cornell University Press, 1992).

$71 \quad$ Marcus Rediker has attempted the rehabilitation of Atlantic pirates rather as Hobsbawm did for bandits. See Marcus Rediker, Outlaws of the Atlantic: Sailors, Pirates and Motley Crews in the Age of Sail (London: Verso, 2014); Villains of All Nations: Atlantic Pirates in the Golden Age (London: Verso, 2004).

72 Daniel J. Vitkus (ed), Introduced by Nabil Matar, Piracy, Slavery and Redemption: Barbary Captivity Narratives from Early Modern England (New York: Columbia University Press, 2001), pp.11-12.

73 Corsair is an Italian loanword, adopted into Arabic in order to mark the distinction with pirate, known as liss al-bahr (sea-robber). J. B. Kelly, C.H. Imber, Ch. Pellat, 'Kursān', Encyclopaedia of Islam (second edition, Leiden: 1960-2004).

$74 \quad$ Giovanni Bonello, 'Pirates in the Early British Era: The Malta Connections', The Malta Historical Society, 2010, http://www.mhs.eu.pn/60/60_21.html.

75 Bonello, 'Pirates in the Early British Era'.

76 Bonello, 'Pirates in the Early British Era'.

77 Clancy-Smith, Mediterraneans North Africa and Europe in an Age of Migrations, $c$. 1800-1900 (Berkeley: University of California Press), pp.171. 
78 Marinos Sariyannis, “ “Neglected Trades”: Glimpses into the $17^{\text {th }}$ Century Istanbul Underworld’, Turcica, vol.38, 2006, pp.155-179, p.162.

79 'Kursān', Encyclopaedia of Islam.

so Marinos Sariyannis, 'Images of the Mediterranean in an Ottoman Pirate Novel from the Late Seventeenth Century', The Journal of Ottoman Studies, vol. 39, 2012, pp.189-204'.

$81 \quad$ Clancy-Smith, Mediterraneans, p.177.

$82 \quad$ Clancy-Smith, Mediterraneans, p.172-3

83 Jiři Cejpek, 'Iranian Folk Literature', Jan Rypka (ed), History of Iranian Literature (Dordrecht: D. Reidel, 1968), pp. 654-5.

84 Sariyannis, " "Neglected Trades”', p.172.

85 Sariyannis, “ “Neglected Trades”', p.172-3.

86 The ideological similarity between social bandit and luti tropes has been examined by Asghar Fathi, 'The Role of the 'Rebels' in the Consitutional Movement in Iran', International Journal of Middle East Studies, vol.10, no.1, 1979, pp.55-66;

Anja Pistor-Hatem, 'Sattar Khan', Encyclopaedia Iranica, 2009; 'The Iranian Constitutional Revolution as lieu(x) de mémoire: Sattar Khan’, H. E. Chehabi and Vanessa Martin (eds) Iran's Constitutional Revolution: Popular Politics, Cultural Transformation and Transnational Connections (New York and London: I. B Tauris, 2010.)

87 For the lutis in Iran see Vanessa Martin, The Qajar Pact: Bargaining, Protest and the State in Nineteenth-Century Persia (New York and London: I. B Tauris, 2005), pp.113-132; for the qabadays see Phillip S. Khoury, 'Abu Ali al-Kilawi: A Damascus Qabaday', Edmund Burke 111 and David N. Yaghoubian (eds) Struggle and Survival in the Modern Middle East (Berkeley: University of California Press, 2006), pp.152-163.

88 Martin, The Qajar Pact.

89 Fathi, 'The Role of the "Rebels”', p.57.

90 Barkey, Bandits and Bureaucrats, p.181-2.

91 Barkey, Bandits and Bureaucrats, p.181; Judith M. Wilks, 'The Persianization of Köroğlu: Banditry and Royalty in Three Versions of the Köruğlu "Destan," Asian Folklore Studies, vol.60, no.2, 2001, pp.305-318.

92 The story of Abdun is drawn from Hart, Banditry in Islam, pp.37-40. See also Emile Violard, Le Banditisme en Kabylie (A. Savine: Paris, 1895).

$93 \quad$ Jean Déjeux, 'Un Bandit d'Honneur dans l'Aurès, de 1917 a 1921', Revue de l'Occident musulman et de la Méditerranée, no.26, 1978, pp.35-54. Ben Zelmat's story is summarized by Hart, Banditry in Islam, p. 42-45. see also Fanny Colonna, Le Meunier, les moines et le bandit: Des vies quotidiennes dans l'Aurès (Algerie) du xxe siècle (France: Sindbad, 2010).

$94 \quad$ Cited by Déjeux, 'Un Bandit d’Honneur’, p.42.

95 Déjeux, 'Un Bandit d’Honneur', p.45.

96 For examples see Déjeux, ‘Un Bandit d’Honneur’, pp.46-49.

97 For Sattar Khan see Pistor-Hatem, 'Sattar Khan', Encyclopaedia Iranica; ‘The Iranian Constitutional Revolution as lieu(x) de mémoire'. Sattar Khan was perhaps more Pancho Villa than Zapata.

$98 \quad$ Reza Afshari, 'The Historians of the Constitutional Movement and the Making of the Iranian Populst Tradition', International Journal of Middle East Studies, vol.25, no.3, 1993, pp.477-494.

99 Fathi, 'The Role of the "Rebels", pp.62-3.

100 Hobsbawm, Bandits, p.35. 
101 Ryan Gingeras, 'Beyond Istanbul's 'Laz Underworld': Ottoman Paramilitarism and the Rise of Turkish Organised Crime’, Contemporary European History, vol.19, no.3, 2010, pp.215-230. 